\title{
REVIEW
}

\section{Anti-atherogenic Actions of High-density Lipoprotein through Sphingosine 1-Phosphate Receptors and Scavenger Receptor Class B Type I}

\author{
FuMiKAZU OKAJIMA, KoICHI SATO AND TAKAO KIMURA* \\ Laboratory of Signal Transduction, Institute for Molecular and Cellular Regulation, Gunma University, Maebashi 371-8512, Japan \\ *Department of Clinical Laboratory Medicine, Gunma University Graduate School of Medicine, Maebashi 371-8511, Japan
}

\begin{abstract}
Plasma high-density lipoprotein (HDL) is a potent anti-atherogenic factor, a critical role of which is thought to be reverse cholesterol transport through the lipoprotein-associated apolipoprotein A-I (apoA-I). HDL also carries a potent bioactive lipid mediator, sphingosine 1-phophate (S1P), which exerts diverse physiological and pathophysiological actions in a variety of biological systems, including the cardiovascular system. In addition, HDL-associated apoA-I is known to stimulate intracellular signaling pathways unrelated to transporter activity. Mounting evidence indicates that multiple antiatherogenic or anti-inflammatory actions of HDL independent of cholesterol metabolism are mediated by the lipoproteinassociated S1P through S1P receptors and by apoA-I through scavenger receptor class B type I.
\end{abstract}

Key words: High-density lipoprotein, Apolipoprotein A-I, Sphingosine 1-phosphate, Scavenger receptor class B type I

(Endocrine Journal 56: 317-334, 2009)

\begin{abstract}
A BALANCE in the concentrations between low-density lipoprotein (LDL) and high-density lipoprotein (HDL) in plasma is a critical biomarker for the initiation and development of atherosclerosis $[1,2]$. High levels of LDL and low levels of HDL are thought to increase the risk of cardiovascular diseases, including atherosclerosis. Plasma lipoproteins are critical for lipid transport and the control of cholesterol metabolism. LDL provides cholesterol to cells through LDL receptors and scavenger receptors. On the other hand, HDL removes excess cholesterol from the cells in peripheral tissues, including artery walls, and transports it to the liver and excretes it as bile acids through scavenger receptor class B type I (SR-BI) [3]. The so-called reverse cholesterol transport is thought to be an important anti-atherogenic actions of HDL [3]. Recent studies, however, have suggested that HDL ex-
\end{abstract}

Received: August 21, 2008

Accepted: August 21, 2008

Correspondence to: Fumikazu OKAJIMA, Ph.D., Laboratory of Signal Transduction, Institute for Molecular and Cellular Regulation, Gunma University, Maebashi 371-8512, Japan erts a variety of anti-atherogenic or anti-inflammatory actions independent of changes in cholesterol metabolism. For example, HDL inhibits LDL oxidation, smooth muscle cell migration, platelet aggregation, and endothelial dysfunction [4-8]. HDL is composed of metabolic enzymes, such as pronases; apolipoproteins, such as apoA-I and apoE; and lipid components, such as cholesterol, phospholipids, and triglycerides. In addition, recent studies have demonstrated that HDL carries sphingosine 1-phosphate (S1P) $[9,10]$ and related lysosphingolipids $[11,12]$. In addition, HDL-associated apoA-I is known to stimulate intracellular signaling pathways unrelated to transporter activity. In the present review, we focus on the role of HDL-associated S1P and apoA-I in the lipoprotein regulation of cardiovascular cell activities not directly related to cholesterol metabolism.

\section{Production of S1P and its receptor systems}

Synthetic pathways, receptor systems, and signaling pathways of S1P are summarized in Fig.1. S1P is 
synthesized by sphingosine kinase (SphK) in the cells. Two types of SphK have been identified: SphK1 in cytoplasm and SphK2 in nuclear fractions. Although the differential role of SphK subtypes is not completely understood, SphK1 is involved in proliferation and anti-apoptosis, and SphK2 appears to exert opposite actions such as the inhibition of proliferation [13, 14]. SphKs thus usually exist in intracellular compartments; however, recent studies have indicated that $\mathrm{SphK}$ is released into extracellular space and synthesizes S1P in the presence of its substrate sphingosine and ATP [15]. Since platelets and erythrocytes express very low activity of S1P lyase, the S1P-degrading enzyme, these cell types maintain high levels of S1P content [16]. S1P is present at 200 to $900 \mathrm{nM}$ in plasma $[5,17,18]$. Erythrocytes are now thought to be a major source of plasma S1P [19]. In a recent study, however, vascular endothelium was also proposed as a source of plasma S1P [20]. Platelets may supply S1P at high levels at the locus of clot formation [16]. Autotaxin, a tumor cell motility-stimulating factor, has been shown to have lysophospholipase D activity that produces lysophosphatidic acid (LPA) from lysophosphatidylcholine (LPC) [21]. Autotaxin potentially generates S1P from SPC, although the role of the enzyme in S1P production remains to be established.

Five subtypes of $\mathrm{S} 1 \mathrm{P}$ receptors, $\mathrm{S}_{1} \mathrm{P}_{1-5}$, which are coupled to heterotrimeric $G$ proteins, have been iden-

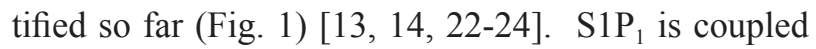
to $\mathrm{G}_{\mathrm{i}} ; \mathrm{S}_{1} \mathrm{P}_{2}$ and $\mathrm{S}_{1} \mathrm{P}_{3}$ are coupled to $\mathrm{G}_{\mathrm{i}}, \mathrm{G}_{12 / 13}$, and $\mathrm{G}_{\mathrm{q}}$; and $\mathrm{S}_{1} \mathrm{P}_{4}$ and $\mathrm{S}_{1} \mathrm{P}_{5}$ are coupled to $\mathrm{G}_{\mathrm{i}}$ and $\mathrm{G}_{12 / 13}$. S1P $\mathrm{S}_{1} \mathrm{P}_{3}$, and $\mathrm{S}_{1} \mathrm{P}_{4}$ have the potential to be coupled to $\mathrm{G}_{\mathrm{s}}$ [22-24]. The heterotrimeric $G$ proteins mediate the regulation of diverse intracellular signaling pathways. For example, $G_{i}$ is linked to adenylyl cyclase, mitogenactivated protein kinases (MAPKs), and phosphatidyl inositol 3-kinase (PI3K), leading to changes in motility, cell survival, inflammatory response, and morphogenesis. $\mathrm{G}_{\mathrm{q}}$ is linked to phospholipase $\mathrm{C}$ and $\mathrm{Ca}^{2+}$ signaling, leading to changes in the constriction of smooth muscle cells (SMCs), and $\mathrm{G}_{12 / 13}$ is linked to Rho signaling, leading to changes in motility and morphogenesis. $\mathrm{S}_{1} \mathrm{P}_{1-3}$ receptors are ubiquitously expressed, $\mathrm{S}_{\mathrm{P}} \mathrm{P}_{4}$ is primarily in lymphoid and hematopoietic tissues, and $\mathrm{S}_{1} \mathrm{P}_{5}$ is in the brain and spleen [13, 14, 22-25]. $\mathrm{S}_{1} \mathrm{P}_{1-3}$ receptors are usually expressed in cardiovascular system. Biological roles of S1P receptors have been characterized using S1P receptor-null mice [26]. The essential role of $\mathrm{S}_{1} \mathrm{P}_{1}$ in vascular development has been evidenced by the finding that $\mathrm{S}_{1} \mathrm{P}_{1}$-null embryos die at E12.5 to E14.5 due to defects in vascular maturation despite normal vasculogensis and angiogenesis [27]. Although $\mathrm{S}_{1} \mathrm{P}_{2}$-null mice do not have any obvious abnormalities in appearance, $\mathrm{S}_{1} \mathrm{P}_{2}$ deficiency induces hearing loss [28] and pathological angiogenesis in the retina [29] due to vascular dysfunction in adult mice. $\mathrm{S}_{1} \mathrm{P}_{3}$-null mice also showed no obvious phenotypic abnormalities [23]; however, a variety of effects on the cardiovascular system have been reported. The roles of lysophospholipid receptors, including S1P receptors and LPA receptors, in addition to lysophospholipid-producing enzymes, including SphKs and autotaxin, obtained using genetic null mice have been summarized in an excellent recent review [26].

$\mathrm{S}_{1} \mathrm{P}_{1-3}$ receptors all have been shown to be expressed in endothelial cells (ECs) [30]. However, in human aortic ECs and human umbilical vein endothelial cells (HUVECs), both widely used as model human ECs, ${\mathrm{S} 1 \mathrm{P}_{2}}_{2}$ receptor expression was not detected [31-33]. In vascular smooth muscle cells (VSMCs), the differential expression of S1P receptor subtypes has been reported: adult medial VSMCs express $\mathrm{S}_{1} \mathrm{P}_{2}$ and $\mathrm{S}_{1} \mathrm{P}_{3}[33,34]$, whereas pup intimal VSMCs express $\mathrm{S}_{1} \mathrm{P}_{1}$ in addition to $\mathrm{S}_{1} \mathrm{P}_{2}$ and $\mathrm{S}_{1} \mathrm{P}_{3}$ [34]. In cardiomyocytes, $\mathrm{S}_{1} \mathrm{P}_{1-4}$ receptors seem to be expressed [35]. Human monocytes and macrophages express $\mathrm{S}_{1} \mathrm{P}_{1}$, $\mathrm{S}_{1} \mathrm{P}_{2}$, and $\mathrm{S}_{1} \mathrm{P}_{4}$. During the differentiation of monocytes into macrophages, $\mathrm{S}_{1} \mathrm{P}_{3}$ is induced [36].

\section{S1P actions in the cardiovascular system}

S1P has been shown to exert diverse physiological and pathophysiological actions in the cardiovascular system, depending on the expression profile of S1P receptor subtypes.

\section{Proliferation and migration of SMCs}

S1P stimulates DNA synthesis and proliferation and inhibits the migration of adult-medial VSMCs $[33,34,37]$. The proliferation and migration of VSMCs are thought to occur under pathological conditions of atherosclerosis and restenosis following angioplasty. As described above, adult-medial VSMCs express $\mathrm{S}_{1} \mathrm{P}_{2}$ and $\mathrm{S}_{1} \mathrm{P}_{3}$ receptors, whereas pup-intimal VSMCs express $\mathrm{S}_{1} \mathrm{P}_{1}$ in addition to $\mathrm{S}_{\mathrm{P}} \mathrm{P}_{2}$ and $\mathrm{S} 1 \mathrm{P}_{3}$ receptors $[33,34]$. With respect to the migratory ac- 


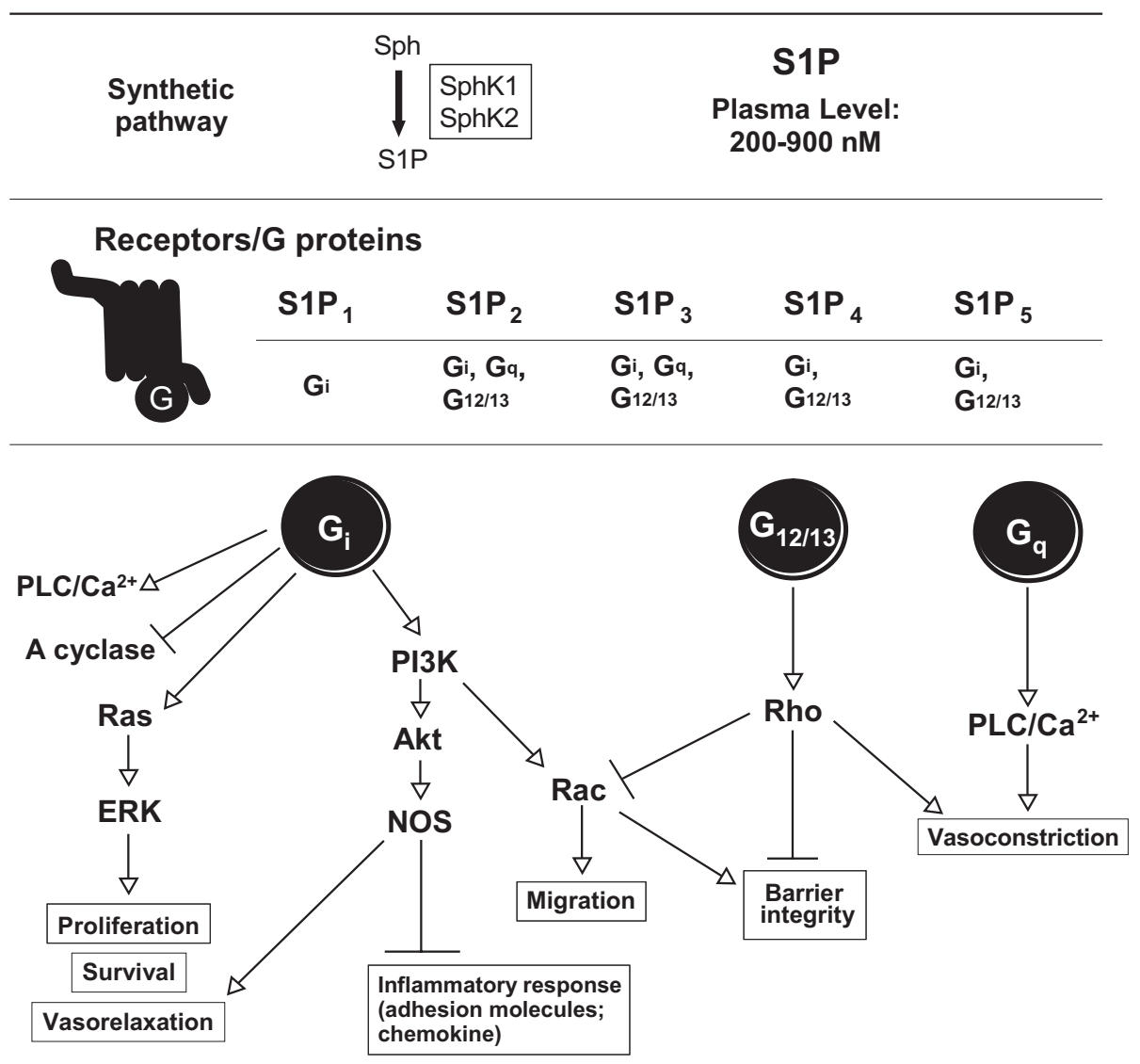

Fig. 1. S1P receptors and their signaling pathways

Five subtypes of $\mathrm{S} 1 \mathrm{P}$ receptors, $\mathrm{S}_{1} \mathrm{P}_{1-5}$ receptors, have been identified. The respective $\mathrm{S} 1 \mathrm{P}$ receptor is coupled to more than one heterotrimeric G protein. In addition, each S1P receptor has the potential to be coupled with G-proteins other than those listed in the figure; for example, $\mathrm{S}_{1} \mathrm{P}_{1}$ receptors may be coupled to $\mathrm{G}_{12 / 13}$, while $\mathrm{S}_{2} \mathrm{P}_{2}, \mathrm{~S}_{1} \mathrm{P}_{3}$, and $\mathrm{S}_{1} \mathrm{P}_{4}$ receptors may be coupled to Gs. The heterotrimeric $G$ proteins mediate the regulation of diverse intracellular signaling pathways, thereby modulating a variety of cellular activities. Sph, sphingosine; SphK, sphingosine kinase; PLC, phospholipase C; A cyclase, adenylyl cyclase; PI3K, phosphatidylinositol 3-kinase. See text for more details.

tivity of cells, $\mathrm{S}_{2} \mathrm{P}_{2}$ is characterized as an inhibitory G-protein-coupled receptor, while other S1P receptor subtypes are stimulatory receptors [38]. Takuwa and his colleagues demonstrated that $\mathrm{S}_{1} \mathrm{P}_{2}$ negatively regulates Rac activity through $\mathrm{G}_{12 / 13}$ and Rho signaling pathways, thereby inhibiting cell migration and membrane ruffling in $\mathrm{S}_{1} \mathrm{P}_{2}$-trasfected Chinese hamster ovary $(\mathrm{CHO})$ cells [38-40]. Consistent with the results of the CHO cells, S1P inhibited PDGF-induced Rac activation and cell migration via $\mathrm{S}_{1} \mathrm{P}_{2}$ through the $\mathrm{G}_{12 / 13} /$ Rho pathway in adult-medial VSMCs [41-44].

The transfection of $\mathrm{S}_{1} \mathrm{P}_{1}$ receptors into adult-medial VSMCs enhanced their proliferative response to S1P via $G_{i}$ in association with the induction of S6 kinase activation and the expression of cyclin D1. S1P 1 re- ceptor expression converted the migration response to S1P from inhibition to stimulation [34]. Lockman et al. showed that S1P regulates proliferation by the extracellular signal-regulated kinase (ERK)-dependent activation of Ets-like protein-1 (Elk-1) and differentiation by the RhoA-dependent activation of myocardin-related transcriptional factor-A (MRTF-A) [45]. In response to acute balloon injury of rat carotid artery, $\mathrm{S}_{1} \mathrm{P}_{1}$ and $\mathrm{S}_{1} \mathrm{P}_{3}$ receptors were increased, whereas $\mathrm{S}_{1} \mathrm{P}_{2}$ receptors were decreased [46]. The administration of the $\mathrm{S}_{1} \mathrm{P}_{1} / \mathrm{S}_{1} \mathrm{P}_{3}$ antagonist decreased injuryinduced neointimal hyperplasia. The S1P-induced proliferation of SMCs was inhibited by the $\mathrm{S}_{1} \mathrm{P}_{1} / \mathrm{S}_{1} \mathrm{P}_{3}$ antagonist, which was associated with the expression of SMC differentiation marker genes, SM $\alpha$-action and 
smooth muscle myosin heavy chain (SMMHC), in vitro. Conversely, S1P-induced proliferation was enhanced by the $\mathrm{S}_{1} \mathrm{P}_{2}$ antagonist, which was associated with the attenuation of the expression of the differentiation marker genes. The authors concluded that $\mathrm{S}_{1} \mathrm{P}_{1}$ and $\mathrm{S}_{1} \mathrm{P}_{3}$ receptors promote, whereas $\mathrm{S}_{1} \mathrm{P}_{2}$ receptors antagonize, SMC proliferation and phenotypic modulation [46]. The inhibitory role of $\mathrm{S}_{1} \mathrm{P}_{2}$ receptors for SMC proliferation and migration was further supported by the recent finding that large neointima lesion formation is induced in $\mathrm{S}_{1} \mathrm{P}_{2}$-null, but not in wildtype, arteries by ligation of the left carotid artery [47].

\section{SMC contraction}

$\mathrm{S} 1 \mathrm{P}$ has been reported to constrict renal and mesenteric microvessels [25]. S1P also induced vasoconstriction of cerebral arteries dependent on the Rho signaling pathway [48, 49], whereas in the aorta, S1P did not induce significant vasoconstriction and RhoA activation [49]. The lower expression of $\mathrm{S}_{1} \mathrm{P}_{2}$ and $\mathrm{S}_{1} \mathrm{P}_{3}$ receptors in the aorta, compared with those in cerebral arteries, may attribute to the lack of vasoconstriction of aorta [49]. In cerebral arteries, $\mathrm{S}_{1} \mathrm{P}_{3}$ receptors may be responsible for vasoconstriction, as evidenced by the finding that the anti-sense gene against $\mathrm{S}_{\mathrm{P}} \mathrm{P}_{3}$ receptors, but not $\mathrm{S}_{1} \mathrm{P}_{2}$ receptors, significantly inhibited $\mathrm{S} 1 \mathrm{P}$-induced contraction [50]. The role of $\mathrm{S}_{1} \mathrm{P}_{3}$ receptors in the S1P-induced contraction has recently been confirmed in cerebral arteries isolated from $\mathrm{S}_{1} \mathrm{P}_{3}$ null mice [51]. The in vivo administration of S1P decreased myocardial perfusion, possibly reflecting the constriction of coronary arteries. The decrease in the myocardial perfusion was blocked in $\mathrm{S}_{1} \mathrm{P}_{3}$-deficient mice, suggesting the role of $\mathrm{S}_{1} \mathrm{P}_{3}$ receptors in vasoconstriction [52]. Ohmori et al., however, reported that $\mathrm{S} 1 \mathrm{P}$ induces the contraction of coronary artery SMCs via $\mathrm{S}_{1} \mathrm{P}_{2}$ based on the finding of the inhibition of $\mathrm{S} 1 \mathrm{P}$ action by the $\mathrm{S}_{1} \mathrm{P}_{2}$-receptor antagonist JTE013 [53]. The vasoconstriction of vascular arteries in response to S1P may be mediated by $\mathrm{Ca}^{2+}$ and Rho signaling pathways in SMCs, while S1P-induced vasorelaxation is likely mediated by endothelial NO synthesis and subsequent cGMP production in SMCs [25].

\section{Angiogenesis, proliferation, and migration of ECs}

S1P has been shown to stimulate angiogenesis, which is composed of several EC functions, includ- ing migration, proliferation, and morphogenesis. Lee et al. [31] showed that $\mathrm{S} 1 \mathrm{P}$ activates angiogenesis through Rho- and Rac-coupled adherens junction assembly. $\mathrm{S}_{1} \mathrm{P}_{1}$ and $\mathrm{S}_{1} \mathrm{P}_{3}$ receptors mediate Rac-induced cortical action formation and Rho-induced stress fiber formation, respectively, in association with the localization of VE-cadherin and catenin at cell-cell junctions. Both $\mathrm{S}_{1} \mathrm{P}_{1}$ and $\mathrm{S}_{1} \mathrm{P}_{3}$ receptors are responsible for EC morphogenesis into capillary-like networks through both $\mathrm{G}_{\mathrm{i}} /$ Ras/ERK-mediated endothelial survival and Rho- and Rac-mediated adherence junction assembly. They also showed that $\mathrm{S} 1 \mathrm{P}$ synergistically potentiated FGF-2- and VEGF-induced angiogenesis in vivo [31]. The EC survival or anti-apoptotic action of $\mathrm{S} 1 \mathrm{P}$, mainly via $\mathrm{S}_{1} \mathrm{P}_{1}$ receptors and partly $\mathrm{S}_{1} \mathrm{P}_{3}$ receptors, is associated with eNOS activation and subsequent NO synthesis, which are regulated by $\mathrm{G}_{\mathrm{i}} /$ phospholipase $\mathrm{C} / \mathrm{Ca}^{2+}$ signaling [54]. The $\mathrm{G}_{\mathrm{i}}$-dependent S1P-induced stimulation of proliferation and tube formation was also accompanied by the stimulation of migration [32, 55]. Migration response to S1P seems to be mediated via both $\mathrm{S}_{1} \mathrm{P}_{1}$ and $\mathrm{S}_{1} \mathrm{P}_{3}$ receptors [32, $55,56]$ through mechanisms involving Rho $[56,57]$ and PI3K/Akt/Rac [41, 58, 59]. S1P-mediated migration requires p38MAPK $[32,56]$, whereas the proliferation response to S1P is dependent on the Ras/ERK pathway [31, 32]. The role of Rac was confirmed by inhibition by a dominant-negative Rac of S1P-induced migration of HUVECs [41]. The forced expression of $\mathrm{S}_{1} \mathrm{P}_{2}$ receptors in HUVECs caused the Rhodependent inhibition of Rac and migration activities [41]. The $\mathrm{S}_{1} \mathrm{P}_{2}$-mediated and Rho-dependent inhibition of migration was confirmed in other cell types, such as cancer cells [60-62] and VSMCs [44]. Inoki et al. showed that, in mouse vascular ECs endogenously expressing $\mathrm{S}_{1} \mathrm{P}_{2}$ and $\mathrm{S}_{1} \mathrm{P}_{3}$ receptors but not $\mathrm{S}_{1} \mathrm{P}_{1}$ receptors, $\mathrm{S}_{1} \mathrm{P}_{2}$ receptors exert inhibitory effects on Rac, migration, and angiogenesis [63]. Skoura et al. showed that endothelial $\mathrm{S}_{1} \mathrm{P}_{2}$ receptors are strongly induced during hypoxic stress in the retina and their stimulation may cause cyclooxygenase-2 (COX-2) induction, eNOS suppression, and pathological angiogenesis [29]. The pathological angiogenesis may be a secondary response to increased inflammatory COX-2 induction and eNOS suppression, both of which are mediated by the $\mathrm{S}_{1} \mathrm{P}_{2} /$ Rho signaling pathway because both enzymes have been shown to mediate positive and negative retinal angiogenesis, respectively [29].

Angiogenesis is an important therapeutic target 
against tumors. The small interfering RNA for $\mathrm{S}_{1} \mathrm{P}_{1}$ receptors $\left(\mathrm{S}_{1} \mathrm{P}_{1}\right.$-siRNA) specifically silenced the cognate transcript in ECs and inhibited EC migration in vitro and the growth of neovessels in subcutaneous implants of Matrigel in vivo. Moreover, the local injection of $\mathrm{S}_{1} \mathrm{P}_{1}$-siRNA into established tumors inhibited vascular stabilization and angiogenesis, which resulted in dramatic suppression of tumor growth in vivo [64]. The anti-S1P antibody has been reported to effectively reduce the growth, invasion, and angiogenesis of tumors [65].

\section{Barrier integrity of ECs}

S1P enhances the barrier integrity of several types of ECs, including bovine and human pulmonary artery ECs and lung microvascular ECs, as shown by an increase in transmonolayer electrical resistance (TER) [66]. S1P also reverses barrier dysfunction elicited by thrombin. S1P-mediated barrier enhancement was dependent upon $\mathrm{G}_{\mathrm{i}}$ protein-coupled $\mathrm{S}_{\mathrm{P}} \mathrm{P}_{1}$ receptors and, to a lesser extent, upon $\mathrm{S}_{1} \mathrm{P}_{3}$ receptors. The S1Pinduced promotion of barrier integrity requires Rac activation and p21-associated kinase-dependent endothelial cortical actin assembly with the recruitment of cofilin [66]. S1P also induces platelet-endothelial cell adhesion molecule (PECAM)- 1 tyrosine phosphorylation through $\mathrm{G}_{\mathrm{i}}$ and subsequent Src and Fyn in HUVECs [67]. The PECAM-1 phosphorylation may enable the recruitment of SHP-2 and tyrosine-phosphorylated $\beta$-catenin, facilitate the dephosphorylation of $\beta$-catenin, allow the reconstitution of adherens junctions, and finally stimulate barrier integrity [68, 69]. The role of $\mathrm{S}_{1} \mathrm{P}_{3}$ receptors in barrier integrity is controversial: a recent study showed that the silencing of $\mathrm{S}_{1} \mathrm{P}_{3}$ receptors abolished the permeability response to lipopolysaccharide (LPS) and other edemagenic agents [70]. Although Rho kinase is required for barrier integrity, as evidenced by its inhibition by the Rho kinase inhibitor, the strong Rho activation without Rac activation leads to barrier disruption, which explains the barrier disruption of the cells treated with thrombin and the higher concentrations of S1P at more

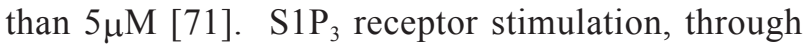
$\mathrm{G}_{12 / 13}$, causes Rho activation $[25,31,72]$. The overexpression of $\mathrm{S}_{1} \mathrm{P}_{2}$ receptors in HUVECs resulted in the Rho/Rho kinase/phosphatase and tensin homolog (PTEN)-dependent disruption of adherens junctions, the stimulation of stress fibers, and an increase in par- acellular permeability [73]. The activation of PTEN may cause the inhibition of PI3K/Akt-mediated Rac activation, which plays a pivotal role in the regulation of barrier integrity. The treatment of HUVECs with $\mathrm{S}_{1} \mathrm{P}_{2}$ antagonist JTE013 potentiated the $\mathrm{S}_{1} \mathrm{P}_{1}$ dependent formation of cortical actin and the stimulation of adherens junction assembly, thereby improving barrier integrity [73]. Thus, $\mathrm{S}_{1} \mathrm{P}_{2}$ and $\mathrm{S}_{1} \mathrm{P}_{3}$ receptors seem to counteract the $\mathrm{S}_{1} \mathrm{P}_{1}$-mediated promotion of endothelial barrier integrity.

The disruption of barrier integrity occurs during the inflammatory disease state, such as acute lung injury and acute respiratory distress syndrome, resulting in the increase in vascular permeability and the exudation of fluid and protein across ECs. The administration of S1P and its analogue FTY720 through vasculature reduced endotoxin LPS-induced lung injury assessed by microvascular permeability and inflammation in vivo $[71,74]$. On the other hand, S1P administration via the airway, but not via the vasculature, in-

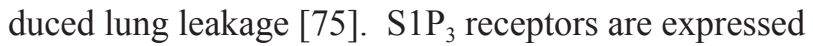
on both type I and type II alveolar epithelial cells but not on vascular endothelium. Wild-type but not $\mathrm{S}_{1} \mathrm{P}_{3}$ null mice showed a disruption of pulmonary epithelial tight junctions in response to S1P in association with the loss of ZO-1 and claudin-18. S1P synergized with pro-inflammatory tumor necrosis factor (TNF)- $\alpha$, resulting in the enhancement of pulmonary edema and mortality. These results suggest that $\mathrm{S} 1 \mathrm{P}$, synergistically with TNF- $\alpha$ reduced epithelial integrity, possibly through the $\mathrm{S}_{1} \mathrm{P}_{3}$-mediated Rho signaling pathway, thereby resulting in pulmonary leakage [75].

\section{Endothelial adhesion and inflammatory actions}

S1P at a $\mu \mathrm{M}$ concentration range stimulates the expression of pro-atherogenic adhesion molecules, including intercellular adhesion molecule-1 (ICAM-1) and vascular cell adhesion molecule-1 (VCAM-1), mainly via $\mathrm{S}_{1} \mathrm{P}_{3}$ receptors through the $\mathrm{G}_{\mathrm{i}}$ and $\mathrm{G}_{12 / 13} /$ nuclear factor (NF) $-\kappa B$ pathway in ECs [76-79]. A previous study also suggested that TNF- $\alpha$-induced adhesion molecule expression is mediated by SphKstimulated S1P and subsequent NF- $\kappa \mathrm{B}$ activation [80]. Moreover, S1P triggers the endothelial exocytosis of Weibel-Palade bodies through the phospholipase C signaling pathway in human aortic ECs, although S1P simultaneously regulates endothelial exocytosis by NO synthesis through eNOS activation, which inhib- 
its the exocytosis [81]. Thus, S1P plays a dual role in regulating endothelial exocytosis. Weibel-Palade bodies contain several factors, including P-selectin, von Willebrand factor, and tissue plasminogen activator, which regulate leukocyte trafficking and blood coagulation. An increase in the expression of the adhesion molecules stimulates leukocyte interaction with ECs and cell penetration into subendothelial space or the intima of arterial walls. Thus, the adhesion of leukocytes on ECs is thought to be a critical early step in atherogenesis [82, 83]. Takeda et al. showed that S1P synergistically enhanced the thrombin-induced expression of tissue factor, an essential factor for blood coagulation, through the activation of transcriptional factors NF- $\mathrm{NB}$ and early growth response-1 (Egr-1) in HUVECs [84]. These results imply that S1P exerts detrimental or proatherogenic actions on ECs. Supporting the detrimental role of plasma S1P, Deutschman et al. reported that serum S1P levels of patients with obstructive coronary artery disease were higher than those of healthy control subjects. They proposed that the serum S1P lev$\mathrm{el}$ is a strong predictor of both the occurrence and severity of coronary stenosis [85]. It should be noted, however, that the authors measured the S1P content in serum rather than plasma. Non-specific S1P release from platelets must have occurred during the collection of serum in this study $[16,17]$.

\section{Cardioprotective and anti-atherogenic S1P actions}

As mentioned above, numerous studies have also reported that S1P exerts beneficial or anti-atherogenic actions on vascular ECs. For example, S1P stimulates migration and proliferation or anti-apoptotic action in ECs, which may be important for maintaining intact ECs and repairing injured ECs. S1P also activates eNOS $[58,86]$ and inhibits cytokine-induced adhesion molecule expression [78, 87]. NO synthesis in ECs is critical for the inhibition of adhesion molecule expression [78] and is also involved in vasorelaxation by S1P [25]. The recent studies suggest the involvement of AMP-activated kinase (AMPK) [88] and Akt $[58,86]$ in S1P-induced eNOS activation.

In rat neonatal cardiomyocytes, S1P induced hyperplasia possibly via $\mathrm{S}_{1} \mathrm{P}_{1}$ receptors through the mechanisms involving PI3K, Akt, MAPKs (ERK, p38MAPK, and Jun-N-terminal kinase (JNK)), and p70S6 kinase [35]. However, S1P also rescues cardi- ac myocytes from hypoxic cell death in the same cells [89]. In isolated hearts, the administration of ganglioside GM-1, which activates $\mathrm{SphK}$, reduced creatine kinase release and diminished infarct size in an $\varepsilon$ PKCdependent manner [90]. An SphK inhibitor abolished the GM-1-induced protective effect, suggesting that SphK activation mediates ischemic preconditioning in the isolated heart [91]. S1P administration also improved ischemia/reperfusion-induced injury; however, the S1P effect was independent of $\varepsilon \mathrm{PKC}$ [90]. As discussed below, the extracellular S1P action may be mediated via $\mathrm{S}_{1} \mathrm{P}_{3}$ receptors [92].

Thus, S1P has the potential to exert both proatherogenic and anti-atherogenic actions. As described above, although S1P stimulated the adhesion of monocytes to ECs, the lysolipid simultaneously inhibited the TNF- $\alpha$-induced adhesion of monocytes to ECs. Both stimulatory and inhibitory actions may be mediated by S1P receptors; the stimulatory action involves NF- $\kappa \mathrm{B}$ activation predominantly through the $\mathrm{S}_{1} \mathrm{P}_{3}$ receptor, and the inhibitory action involves $\mathrm{PI} 3 \mathrm{~K} /$ eNOS predominantly through the $\mathrm{S}_{1} \mathrm{P}_{1}$ receptor $[78$, 87]. Thus, when the cells are exposed to exogenous S1P, the level of adhesion molecule expression may be determined by the balance of the stimulatory signal through NF- $\mathrm{KB}$ activation and the inhibitory signal through eNOS activation. What factors determine $\mathrm{S} 1 \mathrm{P}$ as either a pro- or anti-atherogenic signal? A careful examination of the previous literature reveals that the pro-atherogenic or detrimental actions usually require a $\mu \mathrm{M}$ order of S1P, whereas the anti-atherogenic or beneficial actions of S1P are observed at the $\mathrm{nM}$ order. For example, the expression of VCAM-1 and ICAM-1 in ECs requires more than $1 \mu \mathrm{M}$ of S1P $[76,78,80]$, whereas eNOS activation and subsequent inhibitory action on the adhesion molecule expression of S1P were observed at 1-100 $\mathrm{nM}[78,79,87,93]$. Similarly, vasoconstriction of vascular arteries through the $\mathrm{Ca}^{2+}$ and Rho signaling pathways in VSMCs usually requires a $\mu \mathrm{M}$ order of $\mathrm{S} 1 \mathrm{P}$, while vasorelaxation through NO synthesis in ECs and subsequent cGMP production in SMCs needs the nM order of S1P [25]. Pro-atherogenic adhesion molecule expression and vasoconstriction may occur at the platelet clot site, where a very high S1P concentration may be present under the pathological conditions (H. 2). Another important factor that regulates plasma S1P actions may be plasma components, especially lipoproteins, as discussed below. 


\section{Lipoproteins as carriers of S1P}

The affinity of S1P to the specific receptors is estimated to be around 10 to $100 \mathrm{nM}[5,16,23]$, which is much less than its plasma concentration, implying that receptors might be saturated with lipid mediators and fully activated even under basal conditions. However, the S1P dose response curve of inositol phosphate production in $\mathrm{S}_{1} \mathrm{P}_{3}$ receptor-expressing $\mathrm{CHO}$ cells was shifted about one order to the right in the presence of about $10 \%$ of charcoal-treated serum or plasma [9], suggesting that the S1P affinity to the receptors may be much higher under physiological conditions in the presence of plasma components than its affinity estimated by receptor-binding experiments. Even though the plasma was vigorously dialyzed against phosphate-buffered saline, its S1P content was unchanged [9], suggesting that S1P is tightly bound to plasma components and thereby reduces the apparent affinity of S1P binding to the S1P receptors. S1P measurement in the fractions of the density-gradient separation of plasma revealed that S1P is accumulated in lipoprotein fractions with a rank order of HDL $>$ LDL $>$ VLDL and the lowest content was associated with the albumin fraction when expressed as pmol/mg proteins [9, 94]. S1P bound to lipoproteins may be protected from its enzymatic degradation and uptake into the cells. Thus, lipoproteins, especially HDL, seem to serve as carriers of plasma S1P $[5,95]$. A recent study showed that S1P is preferentially enriched in small HDL3 versus large HDL2 [96]. When the HDL-S1P was plotted against HDL-cholesterol, there was a good correlation between them [94]. This result indicates that a person with a high HDL-cholesterol level has a high HDL-S1P level and that S1P may mediate some HDLinduced anti-atherogenic actions.

How S1P is accumulated in plasma lipoprotein fractions remains unclear. ATP-binding cassette (ABC) transporters may be involved in the export of S1P. Kobayashi et al. showed that S1P release from platelets was inhibited by glybenclamide, a non-specific inhibitor of the $\mathrm{ABC}$ transporter [97]. Mitra et al. showed that $\mathrm{ABCC} 1$ is involved in $\mathrm{S} 1 \mathrm{P}$ export from mast cells in response to an albumin-conjugated antigen [98]. The ABCA1 transporter is known to transport cholesterol and phospholipids to lipid-poor apoA-I or apoE, thereby mediating the HDL formation [99-101]. In the central nervous system as well, S1P seems to bind to HDL-like particles [102]. Astroglial cells are major sources of lipoproteins through ABCA1 in the central nervous system. The knock down and knock out of the ABCA1 transporter of astroglial cells showed a remarkable attenuation of S1P release from the cells in association with the reduction of lipoprotein formation, suggesting that lipoprotein formation through $\mathrm{ABCA} 1$ is coupled with $\mathrm{S} 1 \mathrm{P}$ release in astroglial cells [103]. The role of ABCA1, however, has not been proved in the S1P accumulation in plasma lipoproteins.

\section{HDL actions in the cardiovascular system}

HDL has long been known to exert anti-atherogenic action through reverse cholesterol transport. However, a number of studies have shown that HDL also exerts a variety of cellular actions independently of cholesterol metabolism. Two major systems, i.e., S1P/S1P receptors and apoA-I/ scavenger receptor class B type I (SR-BI), have been proposed.

\section{Role of S1P receptors}

Assmann's group found that HDL regulates multiple signaling pathways, including phosphatidylinositol- and phosphatidylcholine-phospholipase $\mathrm{C}$ in fibroblasts [11, 104] and platelets [105], resulting in the stimulation of DNA synthesis and the inhibition of thrombin-induced fibrinogen binding and aggregation, respectively. They also found that HDL inhibits caspases 9 and 3 and apoptosis of ECs through PI3K and Akt activation [12]. Based on the fractionation analysis of the active components of HDL by highperformance liquid chromatography (HPLC), they proposed that sphingosylphosphorylcholine (SPC) and lysosulfatide (LSF) mediate the HDL-induced actions $[11,12]$. Sachinidis et al. reported that lipid molecules closely related to SPC and S1P mediate LDL- and HDL-induced $\mathrm{Ca}^{2+}$ mobilization and ERK activation in VSMCs based on organic solvent purification and subsequent HPLC analysis [106]. As described above, we established a quantitative S1P measurement based on the high affinity and specificity of S1P receptors to S1P [18]. Using this analytical method, we reported that S1P is concentrated in the lipoprotein fraction, especially HDL [9]. The finding that $\mathrm{S} 1 \mathrm{P}$ is concentrated in HDL raises the possibility that cholesterol metabolism-independent actions of 
HDL may be mediated by lipoprotein-associated S1P $[5,96]$. Assmann's group confirmed the existence of S1P in HDL particles, but they proposed that SPC and LSF, in addition to S1P, are responsible for the HDLinduced actions [107]. The roles of SPC and LSF will be discussed later.

When HUVECs were starved for $24 \mathrm{~h}$ without serum, about $50 \%$ of the cells died due to apoptosis. The supplement of either HDL or S1P in the culture medium protected the cells from cell death [10]. Our results suggested that HDL- and S1P-induced cell survival was mediated by the $\mathrm{G}_{\mathrm{i}} / \mathrm{ERK}$ pathways. On the other hand, migration response to HDL and S1P was mediated by the $\mathrm{G}_{\mathrm{i}} / \mathrm{PI} 3 \mathrm{~K} / \mathrm{p} 38 \mathrm{MAPK}$ pathway. Rho signaling may also be involved in the migration response $[10,57]$. In ECs, $\mathrm{S}_{1} \mathrm{P}_{1}$ and $\mathrm{S}_{1} \mathrm{P}_{3}$ are major $\mathrm{S} 1 \mathrm{P}$ receptors. The roles of S1P in HDL-induced cell survival and migration were established by fractionation analysis of the active component by HPTLC and specific inhibition by anti-sense oligonucleotides and siRNAs against S1P receptors [57]. We have suggested that $\mathrm{S}_{1} \mathrm{P}_{1}$ receptors are critical for cell survival and that both $\mathrm{S}_{1} \mathrm{P}_{1}$ and $\mathrm{S}_{1} \mathrm{P}_{3}$ receptors are important for cell migration [57]. HDL has been shown to activate Ras in a PTX-suppressive manner in CHO cells [108]. HDL-associated S1P has been suggested to mediate, through the $\mathrm{G}_{\mathrm{i}} /$ Ras/ERK pathway, lipoprotein-induced angiogenesis in human coronary artery ECs [109]. Nofer et al. reported that HDL, possibly through its associated SPC and LSF, activated PI3K and Akt, resulting in the inhibition of TNF- $\alpha$-induced E-selectin expression [110] and the stimulation of eNOS and subsequent NO synthesis in ECs [107]. They proposed the role of $\mathrm{S}_{1} \mathrm{P}_{3}$ receptors in the HDL-induced eNOS activation based on the inhibition of the S1P actions by $\mathrm{S} 1 \mathrm{P}_{3}$ deficiency [107]. On the other hand, we showed that $\mathrm{S}_{1} \mathrm{P}_{1}$ and, to a lesser extent, $\mathrm{S}_{1} \mathrm{P}_{3}$ mediate HDLinduced eNOS activation and the subsequent inhibition of the expression of adhesion molecules, such as VCAM-1 and ICAM-1 [79]. The predominant role of the $\mathrm{S}_{1 \mathrm{P}}{ }_{1}$ receptor in the activation of eNOS and $\mathrm{PI} 3 \mathrm{~K} /$ Akt pathways has been reported in HUVECs [54,111], bovine aortic ECs [86], and lung microvascular ECs [58]. Moreover, Hedrick's group reported that $\mathrm{S}_{1} \mathrm{P}_{1}$ receptors mediate the inhibition of the adhesion of monocytes to ECs $[87,93]$. A recent study also showed that HDL stimulates EC barrier integrity in association with Akt activation through $\mathrm{S}_{1} \mathrm{P}_{1}$ receptors [112].

Catapano and his colleagues reported that HDL in- duces transforming growth factor (TGF)- $\beta 2$ expression and Smad activation through PI3K/Akt [113] and increases the expression of the long pentraxin 3 (PTX3), an acute phase protein, through $\mathrm{G}_{\mathrm{i}} / \mathrm{PI} 3 \mathrm{~K}$ [114] in ECs. They observed an increased expression of PTX3 mRNA in the aorta of apoA-I-transgenic mice, which keep high levels of HDL compared to apoA-Ideficient mice, which keep low levels of HDL [114]. The siRNA experiments revealed that HDL-induced PTX3 expression was mediated by $\mathrm{S}_{1} \mathrm{P}_{1}$ and $\mathrm{S}_{1} \mathrm{P}_{3}$ receptors but not SR-BI. Moreover, the HDL action was mimicked by S1P and SPC but not by reconstituted HDL (rHDL), in which apoA-I was reconstituted with phosphatidylcholine, further supporting the role of S1P receptors but not that of SR-BI [114].

HDL-like proteins are also present in the follicular fluid of the ovary and induce angiogenesis in association with the activation of ERK, PKC, and Akt in ECs [115]. The HDL-like proteins present in cerebrospinal fluid cause the migration of astroglial cells [102]. In both cases, the HDL-induced actions are mediated through the lipoprotein-associated S1P. In VSMCs, HDL markedly inhibited PDGF-induced migration. The siRNA strategy revealed that the inhibitory migration response to HDL was mediated by $\mathrm{S}_{1} \mathrm{P}_{2}$ receptors [43].

HDL actions mediated by its associated S1P were also reported in isolated tissues and in vivo. Nofer et al. [107] showed that HDL stimulates NO release in human ECs in vitro and induces the vasodilation of isolated aortas in a manner dependent on intracellular $\mathrm{Ca}^{2+}$ and Akt-mediated eNOS activation. These effects of HDL were mimicked by S1P and other lysophospholipids, including SPC and LSF. A deficiency of $\mathrm{S}_{1} \mathrm{P}_{3}$ receptors abolished HDL-induced vasodilation and Akt activation. They also showed that intraartery administration of HDL and these lysophospholipids lowered the mean arterial blood pressure in rats. Although Nofer et al. insisted in their previous papers $[11,12]$ that HDL contains enough SPC and LSF to explain the HDL-induced actions, the roles of SPC and LSF, except for S1P, were not confirmed in HDL actions [57]. The concentration of S1P (100-300 pmol/ mg proteins) in HDL particles has been established [9, $10,96,107]$; however, the concentrations of SPC and LSF in HDL particles have not. Large differences in SPC and LSF concentrations appear in the previous reports [11, 12, 107].

Theilmeier et al. recently showed that HDL and 
S1P dramatically attenuated infraction size in the in vivo mouse model of myocardial ischemia/reperfusion, which was associated with the inhibition of inflammatory neutrophil recruitment and cardiomyocyte apoptosis in the infracted area [92]. They also observed that the HDL- and S1P-induced actions were abolished by pharmacological NOS inhibition and were completely absent in $\mathrm{S}_{1} \mathrm{P}_{3}$-deficient mice. HDL and S1P potently suppressed leukocyte adhesion to activated endothelium under flow and protected rat neonatal cardiomyocytes against apoptosis in vitro. Thus, HDL and its constituent, S1P, acutely protect the heart against ischemia/perfusion injury in vivo via the $\mathrm{S}_{1} \mathrm{P}_{3}-$ mediated and NO-dependent pathway [92]. Monocyte chemoattractant protein-1 (MCP-1) involved in monocyte recruitment to vascular inflammation and is elevated in atherosclerotic lesions. Treatment of VSMCs or isolated aortas with HDL inhibited thrombin-induced MCP-1 mRNA and protein expression, associated with the suppression of NAD(P)H oxidase, ROS production, and Rac1 activation [116]. The HDLinduced actions were abolished by an S1P receptor antagonist, VPC23019, and mimicked by S1P and SPC. Moreover, HDL, S1P, and SPC failed to inhibit MCP-1 production and ROS generation in aortas from $\mathrm{S}_{1} \mathrm{P}_{3}$-deficient mice [116]. These results suggest that HDL-associated S1P and SPC mediate the lipoproteininduced inhibition of ROS and MCP-1 production.

\section{Role of SR-BI}

SR-BI is known to be an important transporter for excretion of the excess cholesterol as bile acids from liver [3]. Yuhanna et al. have shown that HDL, but not LDL, stimulates eNOS in ECs. The HDL-induced activation of eNOS was also observed in caveolae membranes isolated from ECs, in which antibodies to apoA-I or SR-BI completely attenuated the HDL activation of the enzyme. HDL also enhanced endothelium- and NO-dependent relaxation in aortas from wild-type mice but not in aortas from SR-BI-null mice [117]. These results suggest that HDL activates eNOS through apoA-I binding to SR-BI. Recent studies suggest that apoA-I interaction with SR-BI stimulates eNOS through Src, PI3K, and Akt activation [118]. Although it remains poorly understood how apoA-I interaction with SR-BI leads to the Src-mediated PI3K and Akt activation, the involvement of the scaffold protein PDZK1, which contains four PSD-95/Dlg/
ZO-1 (PDZ) domains, has been proposed as a transducer [79, 119, 120] (Fig.2).

It is well known that premenopausal women have a lower risk of developing cardiovascular disease than similarly aged men and postmenopausal women. The NO production in ECs has been shown to exert numerous protective effects in the vascular system, including vasodilation, anti-adhesion, and anti-inflammatory effects. Gong et al. tested the hypothesis that HDL binds to its receptor SR-BI and delivers estrogen to eNOS, thereby stimulating enzyme activity [121]. They showed that HDL isolated from women stimulated eNOS in an SR-BI- and estrogen receptor-dependent manner in human microvascular ECs, whereas HDL isolated from men had minimal activity. Reconstitution experiments revealed that male HDL reconstituted with estrogen (HDL-estrogen), but not LDL-estrogen or bovine serum albumin (BSA)estrogen, effectively stimulated eNOS to the same extent as female HDL. Furthermore, female but not male HDL promoted the relaxation of the isolated femoral artery from control mice but not SR-BI-null mice. These results suggest that the interaction of HDL with SR-BI through apoA-I is not sufficient to stimulate eNOS but may be responsible for delivering estrogen to its receptor. Even though Yuhanna's report did not mention whether HDL was prepared from males or females, the involvement of estrogen receptors was negative [117]. Thus, the antibody to estrogen receptor- $\alpha$, which is colocalized and functionally linked to eNOS in caveolae, was ineffective for the inhibition of the enzyme activity. Furthermore, the results of Nofer et al. [107] were totally different from those of Gong et al. [121]. Nofer et al. showed that female and male HDLs were equally potent for inducing vasodilation in isolated aortic rings. Possible explanations for the discrepancies among the results might be the different sources of arteries used (femoral arteries in Gong's report vs. aortas in Nofer's and Yuhanna's reports) and/or the different precontraction agents (5-hydrosytryptamin in Gong's report vs. phenylephrine in Nofer's and Yuhanna's reports). Interestingly, aortas from SR-BI-deficient mice showed an attenuation of the inhibitory actions of S1P as well as HDL on MCP-1 production, even though the $\mathrm{S}_{1} \mathrm{P}_{3}$ receptor expression remains unchanged by SR-BI deficiency [116]. This result raises the possibility that the $\mathrm{S}_{1} \mathrm{P}_{3}$ receptor signal transduction system is also damaged by SR-BI deficiency. Thus, the attenuation of the HDL 


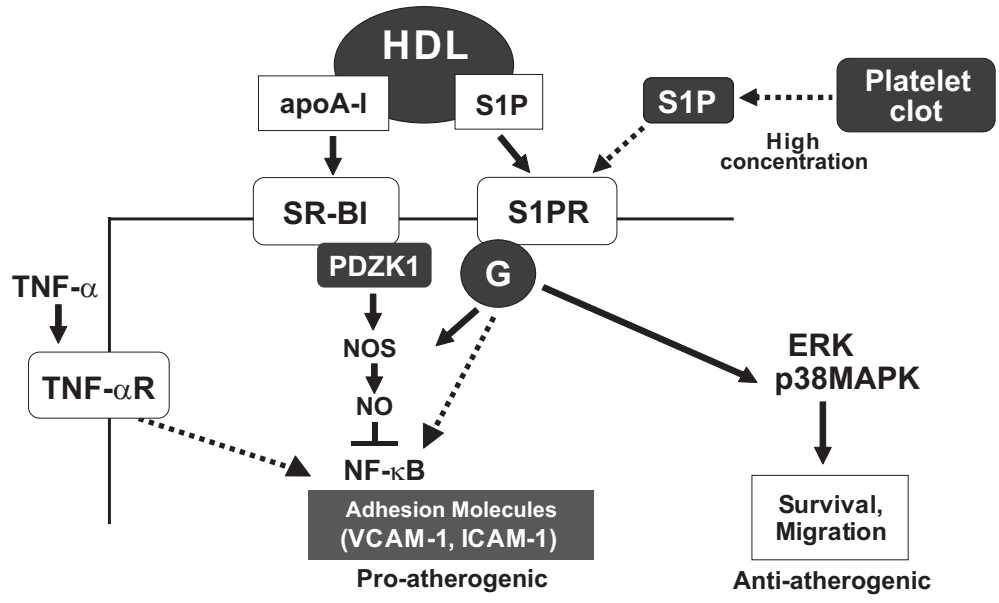

Fig. 2. Roles of S1P receptors and SR-BI in S1P- and HDL-induced pro- or anti-atherogenic actions in ECs

S1P may have at least two pools in plasma, i.e., HDL and the locus where S1P may be released from activated platelets. S1P, regardless of the pool, triggers the respective S1P receptor subtype and activates, through several heterotrimeric G-proteins, a variety of intracellular signaling pathways leading to pro- or anti-atherogenic actions. In the locus where platelet clots are formed, the S1P concentration reaches extremely high levels, which may explain the stimulation of pro-atherogenic pathways. In addition to S1P, apolipoproteins, such as apoA-I, are bound to HDL and stimulate intracellular signaling pathways through

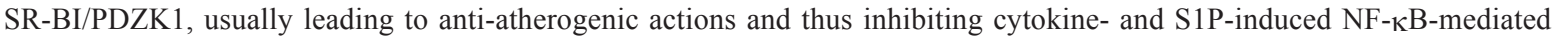
adhesion molecule expression. Solid line represents the pathways leading to anti-atherogenic actions; broken line, to proatherogenic pathways. See text for more details.

actions in the cells or tissues from SR-BI-deficient mice dose not rule out the possible involvement of the $\mathrm{S} 1 \mathrm{P}$ receptor system in lipoprotein actions.

\section{Both SIP receptors and SR-BI may be responsible for $H D L$-induced actions}

As described above, either the S1P receptor or SR$\mathrm{BI}$ is responsible for the HDL-induced activation of eNOS and MAPKs and subsequent cellular responses. Nofer et al. [107] proposed that SR-BI plays a role, through apoA-I, as an anchor for lipoprotein-associated S1P and other lysolipids to interact with S1P receptors to stimulate intracellular signaling pathways. Their proposal is based on the finding that reconstituted apoA-I with cholesterol and phospholipids was ineffective for the stimulation of eNOS and MAPKs, whereas antibodies against apoA-I and SR-BI effectively attenuated the HDL-induced enzyme activation [117]. However, Assanasen et al. found that reconstituted apoA-I with phospholipids but with a reduced level or an absence of cholesterol can stimulate SR$\mathrm{BI}$, resulting in the activation of eNOS and MAPKs. They speculated that cholesterol efflux from the intracellular space was necessary for SR-BI activation by
apoA-I [119].

The ability of rHDL or reconstituted apoA-I with phospholipids but without cholesterol to stimulate eNOS activation was confirmed by us [79]. We have also shown that HDL-induced eNOS activation and the subsequent inhibition of NF- $\mathrm{KB}$-mediated adhesion molecule expression were attenuated by either SR-BI siRNA or S1P receptor siRNA and were completely blocked by the combination of siRNAs against SRBI and S1P receptors in HUVECs. Moreover, rHDL stimulated eNOS activation in a manner sensitive to SR-BI-siRNA but not to S1P receptor-siRNA, and S1P stimulated enzyme activity in an opposite manner [79]. These results suggest that both SR-BI and S1P receptors are involved in the HDL-induced stimulation of intracellular signaling pathways in ECs at least in vitro (Fig. 2). As described above, Theilmeier et al. showed that HDL protected the heart from ischemia/ reperfusion injury via $\mathrm{S}_{1} \mathrm{P}_{3}$ receptors through eNOS activation [92]. However, the same group previously reported that HDL administration increased myocardial perfusion in a manner dependent on eNOS activation, reflecting a vasodilatory effect on coronary circulation in vivo. The vasodilatory effect of HDL was not affected in $\mathrm{S}_{1} \mathrm{P}_{3}$-deficient mice, whereas the vasocon- 
striction effect of S1P was attenuated by the $\mathrm{S}_{1} \mathrm{P}_{3}$ deficiency. These results indicate that SR-BI-mediated, but not $\mathrm{S}_{1} \mathrm{P}_{3}$-mediated, eNOS activation may be involved in the HDL vasorelaxation effect [52]. Thus, both SR-BI and S1P receptors may be important in HDL-induced eNOS activation in the coronary artery in vivo.

Recent studies have shown that rHDL effectively promotes the endothelial progenitor cell (EPC)mediated repair of damaged endothelium [122] and enhances ischemia-induced angiogenesis [123] in vivo through the stimulation of differentiation of EPCs. rHDL also increased circulating EPCs in patients with type 2 diabetes [124]. HDL prevents the apoptosis of EPCs by activating eNOS and inhibiting caspase 3 in vitro [125]. The transplantation of EPCs treated with S1P or its derivative FTY720 into mice with ischemic hind limbs promoted neovascularization. The stimulation of EPCs by S1P was mediated through the activation of the CXCR4-dependent signaling pathway via $\mathrm{S}_{1} \mathrm{P}_{3}$ receptors [126]. Thus, both apoA-I, possibly through SR-BI, and $\mathrm{S} 1 \mathrm{P}$ through $\mathrm{S}_{1} \mathrm{P}_{3}$ have the ability to stimulate EPCs and promote neovascularization.

\section{Role of other targets?}

Norata et al. reported that HDL induces COX-2 expression and prostacyclin release through $\mathrm{p} 38 \mathrm{MAPK}$ [127]. Drew et al. reported that HDL and apoA-I increase eNOS activity by multiple phosphorylations through AMPK and Akt in ECs [128]. Viswambharan et al. showed that rHDL inhibited the endothelial expression of tissue factor, a potent coagulation factor, through the inhibition of RhoA and the stimulation of PI3K but not Akt/eNOS [129]. Although the active components or the responsible receptors have not been characterized in these studies, S1P receptors and/or SR-BI may mediate these actions since the intracellular signaling pathways are usually regulated by these receptors.

The observations described below, however, suggest that there are targets other than S1P receptors and SRBI for HDL which elicit cholesterol metabolism-independent actions. TNF- $\alpha$ and interleukin (IL)- $1 \beta$ are induced in monocytes by direct contact with stimulated T lymphocytes. Hyka et al. showed that adult human serum and HDL display inhibitory activity toward the contact-mediated activation of monocytes by stimulated T cells [130]. Delipidated HDL and purified apoA-I also mimicked the HDL actions. Functional assays and flow cytometry analyses showed that HDLassociated apoA-I inhibited the contact-mediated activation of monocytes by binding to stimulated $\mathrm{T}$ cells. TNF- $\alpha$ and IL-1 $\beta$ have been shown to be essential components in the pathogenesis of immunoinflammatory diseases, implying a new anti-inflammatory activity of HDL-associated apoA-I. The primary target or receptor for apoA-I, however, has not yet been identified [130]. Cholesterol efflux is initiated by apoA-I binding to a specific site of ABCA1, followed by the activation of the transport of cholesterol. Nofer et $a l$. have reported that apoA-I activates Rho signaling pathways (Cdc42, Rac1, and Rho) and MAPKs (JNK, p38 MAPK, and ERK) in ABCA1-transfected human dermal fibroblasts [131]. Experiments with dominant negative mutant and specific activators have revealed that the $\mathrm{Cdc} 42 / \mathrm{JNK}$ pathway is responsible for cholesterol efflux, which suggests that the activation of early intracellular signaling pathways links with ABCA1mediated cholesterol efflux activity. However, the finding that apoA-I activates the Rho signaling and MAPK pathways in addition to Cdc $42 / J N K$ pathways suggests that ABCA1 activation by apoA-I has the potential to regulate a variety of cellular activities other than cholesterol efflux [131]. Similarly, Haidar et al. reported that apoA-I activates cAMP accumulation through the ABCA1 transporter in ABCA1-transfected $\mathrm{CHO}$ cells [132]. In these reports [131, 132], however, whether HDL really activates these early signaling pathways through lipoprotein-associated apoA-I was not examined.

\section{Role of lipoproteins as a regulator of S1P actions}

As described above, HDL inhibits pro-atherogenic cytokine-induced actions through at least dual mechanisms involving not only S1P receptors but also SRBI. The ability of HDL to stimulate the SR-BI system through apoA-I may regulate the ability of plasma S1P to exert pro-atherogenic actions at concentrations present under basal conditions. Indeed, pro-atherogenic adhesion molecule expression elicited by S1P disappeared in the presence of physiological concentrations of HDL in a manner sensitive to SR-BI [79]. Thus, where physiological concentrations of HDL exist, S1P may not exert pro-atherogenic actions.

Whether S1P is present in HDL or LDL may be another factor regulating S1P actions. HDL inhibited the platelet-derived growth factor (PDGF)-induced mi- 
gration of VSMCs through the lipoprotein-associated $\mathrm{S} 1 \mathrm{P} / \mathrm{S}_{1} \mathrm{P}_{2}$ receptors [43]. Although LDL contains S1P to the extent of $20 \sim 40 \%$ of the S1P content in HDL when expressed as pmol/mg proteins [9, 10], PDGFinduced migration was not inhibited by even a high dose of LDL in which sufficient S1P existed to inhibit the migration response to PDGF. On the other hand, LDL, but not HDL, alone stimulates the migration of VSMCs. Thus, whether S1P is present in HDL or LDL seems to determine the apparent migratory activity of S1P in VSMCs. This peculiar observation is explained by the presence of higher levels of LPA in the LDL particle than in the HDL particle. Indeed, when the LDL-associated LPA were degraded by monoglyceride lipase or $\mathrm{LPA}_{1}$ receptors on coronary artery smooth muscle cells (CASMCs) were antagonized by Ki16425, the lipoprotein was able to inhibit PDGFinduced migration through $\mathrm{S}_{1} \mathrm{P}_{2}$ receptors [43]. These results suggest that a balance of LPA and S1P contents in lipoprotein is important to determine whether the lipoprotein is a positive or negative regulator of VSMC migration.

\section{Concluding remarks}

In the present review, we summarized HDL-induced actions independent of cholesterol metabolism. A variety of anti-atherogenic or anti-inflammatory actions of HDL are mediated through S1P/S1P receptors and/ or apoA-I/SR-BI in cells involved in the cardiovascular system, including ECs, SMCs, and cardiomyocytes. Heterotrimeric $\mathrm{G}$ proteins are coupled to several types of S1P receptors to mediate the HDL-associated S1P-induced actions. Similarly, PDZK1 may be coupled to SR-BI to mediate the apoA-I actions. In addition to SR-BI, a transporter, such as ABCA1, has also the potential to mediate the HDL-induced stimulation of intracellular signaling pathways. Although high concentrations of S1P sometimes exert pro-atherogenic or pro-inflammatory actions, these detrimental actions are blocked by HDL through apoA-I/SR-BI. The HDL-cholesterol content is well correlated with that of HDL-apoA-I. However, how the HDL-S1P content is regulated is poorly understood. The finding that HDL-associated S1P mediates a variety of the beneficial lipoprotein-induced effects suggests that the content of S1P in the HDL particle may be another factor which determines the ability of HDL to protect the cardiovascular system.

\section{References}

1. Rader DJ (2003) Regulation of reverse cholesterol transport and clinical implications. Am J Cardiol 92: 42-49.

2. Assmann G, Gotto AM, Jr. (2004) HDL cholesterol and protective factors in atherosclerosis. Circulation 109:8-14.

3. Rader DJ (2006) Molecular regulation of HDL metabolism and function: implications for novel therapies. $J$ Clin Invest 116:3090-3100.

4. Nofer JR, Kehrel B, Fobker M, Levkau B, Assmann G, von Eckardstein A (2002) HDL and arteriosclerosis: beyond reverse cholesterol transport. Atherosclerosis 161:1-16.

5. Okajima F (2002) Plasma lipoproteins behave as carriers of extracellular sphingosine 1-phosphate: is this an atherogenic mediator or an anti-atherogenic mediator? Biochim Biophys Acta 1582:132-137.

6. Nofer JR, Assmann G (2005) Atheroprotective effects of high-density lipoprotein-associated lysosphingolipids. Trends Cardiovasc Med 15:265-271.

7. Keul P, Sattler K, Levkau B (2007) HDL and its sphin- gosine-1-phosphate content in cardioprotection. Heart Fail Rev 12:301-306.

8. Argraves KM, Argraves WS (2007) HDL serves as a S1P signaling platform mediating a multitude of cardiovascular effects. J Lipid Res 48:2325-2333.

9. Murata N, Sato K, Kon J, Tomura H, Yanagita M, Kuwabara A, Ui M, Okajima F (2000) Interaction of sphingosine 1-phosphate with plasma components, including lipoproteins, regulates the lipid receptor-mediated actions. Biochem J 352:809-815.

10. Kimura T, Sato K, Kuwabara A, Tomura H, Ishiwara M, Kobayashi I, Ui M, Okajima F (2001) Sphingosine 1-phosphate may be a major component of plasma lipoproteins responsible for the cytoprotective actions in human umbilical vein endothelial cells. J Biol Chem 276:31780-31785.

11. Nofer JR, Fobker M, Hobbel G, Voss R, Wolinska I, Tepel M, Zidek W, Junker R, Seedorf U, von Eckardstein A, Assmann G, Walter M (2000) Activation of phosphatidylinositol-specific phospholipase $\mathrm{C}$ by HDL-associated lysosphingolipid. Involvement in mi- 
togenesis but not in cholesterol efflux. Biochemistry 39:15199-15207.

12. Nofer JR, Levkau B, Wolinska I, Junker R, Fobker M, von Eckardstein A, Seedorf U, Assmann G (2001) Suppression of endothelial cell apoptosis by high density lipoproteins (HDL) and HDL-associated lysosphingolipids. J Biol Chem 276:34480-34485.

13. Hait NC, Oskeritzian CA, Paugh SW, Milstien S, Spiegel S (2006) Sphingosine kinases, sphingosine 1-phosphate, apoptosis and diseases. Biochim Biophys Acta 1758:2016-2026.

14. Brinkmann V (2007) Sphingosine 1-phosphate receptors in health and disease: mechanistic insights from gene deletion studies and reverse pharmacology. Pharmacol Ther 115:84-105.

15. Venkataraman K, Thangada S, Michaud J, Oo ML, Ai Y, Lee YM, Wu M, Parikh NS, Khan F, Proia RL, Hla $\mathrm{T}$ (2006) Extracellular export of sphingosine kinase1a contributes to the vascular S1P gradient. Biochem $J$ 397:461-471.

16. Yatomi Y (2008) Plasma sphingosine 1-phosphate metabolism and analysis. Biochim Biophys Acta 1780:606611.

17. Yatomi Y, Igarashi Y, Yang L, Hisano N, Qi R, Asazuma N, Satoh K, Ozaki Y, Kume S (1997) Sphingosine 1-phosphate, a bioactive sphingolipid abundantly stored in platelets, is a normal constituent of human plasma and serum. J Biochem 121:969-973.

18. Murata N, Sato K, Kon J, Tomura H, Okajima F (2000) Quantitative measurement of sphingosine 1-phosphate by radioreceptor-binding assay. Anal Biochem 282: 115-120.

19. Pappu R, Schwab SR, Cornelissen I, Pereira JP, Regard JB, Xu Y, Camerer E, Zheng YW, Huang Y, Cyster JG, Coughlin SR (2007) Promotion of lymphocyte egress into blood and lymph by distinct sources of sphingosine-1-phosphate. Science 316:295-298.

20. Venkataraman K, Lee YM, Michaud J, Thangada S, Ai Y, Bonkovsky HL, Parikh NS, Habrukowich C, Hla T (2008) Vascular endothelium as a contributor of plasma sphingosine 1-phosphate. Circ Res 102:669-676.

21. Umezu-Goto M, Kishi Y, Taira A, Hama K, Dohmae N, Takio K, Yamori T, Mills GB, Inoue K, Aoki J, Arai $\mathrm{H}$ (2002) Autotaxin has lysophospholipase D activity leading to tumor cell growth and motility by lysophosphatidic acid production. J Cell Biol 158:227-233.

22. Spiegel S, Milstien S (2003) Sphingosine-1-phosphate: an enigmatic signalling lipid. Nat Rev Mol Cell Biol 4:397-407.

23. Ishii I, Fukushima N, Ye X, Chun J (2004) Lysophospholipid receptors: signaling and biology. Annu Rev Biochem 73:321-354.

24. Meyer zu Heringdorf D, Jakobs KH (2007) Lysophospholipid receptors: signalling, pharmacology and regulation by lysophospholipid metabolism.
Biochim Biophys Acta 1768:923-940.

25. Watterson KR, Ratz PH, Spiegel S (2005) The role of sphingosine-1-phosphate in smooth muscle contraction. Cell Signal 17:289-298.

26. Choi JW, Lee CW, Chun J (2008) Biological roles of lysophospholipid receptors revealed by genetic null mice: An update. Biochim Biophys Acta 1781:531-539.

27. Liu Y, Wada R, Yamashita T, Mi Y, Deng CX, Hobson JP, Rosenfeldt HM, Nava VE, Chae SS, Lee MJ, Liu CH, Hla T, Spiegel S, Proia RL (2000) Edg-1, the $\mathrm{G}$ protein-coupled receptor for sphingosine-1-phosphate, is essential for vascular maturation. J Clin Invest 106:951-961.

28. MacLennan AJ, Benner SJ, Andringa A, Chaves AH, Rosing JL, Vesey R, Karpman AM, Cronier SA, Lee N, Erway LC, Miller ML (2006) The S1P2 sphingosine 1-phosphate receptor is essential for auditory and vestibular function. Hear Res 220:38-48.

29. Skoura A, Sanchez T, Claffey K, Mandala SM, Proia RL, Hla T (2007) Essential role of sphingosine 1-phosphate receptor 2 in pathological angiogenesis of the mouse retina. J Clin Invest 117:2506-2516.

30. Saba JD, Hla T (2004) Point-counterpoint of sphingosine 1-phosphate metabolism. Circ Res 94: 724-734.

31. Lee MJ, Thangada S, Claffey KP, Ancellin N, Liu CH, Kluk M, Volpi M, Sha'afi RI, Hla T (1999) Vascular endothelial cell adherens junction assembly and morphogenesis induced by sphingosine-1-phosphate. Cell 99:301-312.

32. Kimura T, Watanabe T, Sato K, Kon J, Tomura H, Tamama K, Kuwabara A, Kanda T, Kobayashi I, Ohta H, Ui M, Okajima F (2000) Sphingosine 1-phosphate stimulates proliferation and migration of human endothelial cells possibly through the lipid receptors, Edg-1 and Edg-3. Biochem J 348:71-76.

33. Tamama K, Kon J, Sato K, Tomura H, Kuwabara A, Kimura T, Kanda T, Ohta H, Ui M, Kobayashi I, Okajima F (2001) Extracellular mechanism through the Edg family of receptors might be responsible for sphingosine-1-phosphate-induced regulation of DNA synthesis and migration of rat aortic smooth-muscle cells. Biochem J 353:139-146.

34. Kluk MJ, Hla T (2001) Role of the sphingosine 1-phosphate receptor EDG-1 in vascular smooth muscle cell proliferation and migration. Circ Res 89:496-502.

35. Karliner JS (2002) Lysophospholipids and the cardiovascular system. Biochim Biophys Acta 1582: 216221.

36. Duong CQ, Bared SM, Abu-Khader A, Buechler C, Schmitz A, Schmitz G (2004) Expression of the lysophospholipid receptor family and investigation of lysophospholipid-mediated responses in human macrophages. Biochim Biophys Acta 1682:112-119.

37. Bornfeldt KE, Graves LM, Raines EW, Igarashi Y, Wayman G, Yamamura S, Yatomi Y, Sidhu JS, Krebs 
EG, Hakomori S, Russell Ross (1995) Sphingosine-1phosphate inhibits PDGF-induced chemotaxis of human arterial smooth muscle cells: spatial and temporal modulation of PDGF chemotactic signal transduction. J Cell Biol 130:193-206.

38. Takuwa Y, Okamoto Y, Yoshioka K, Takuwa N (2008) Sphingosine-1-phosphate signaling and biological activities in the cardiovascular system. Biochim Biophys Acta 1781:483-488.

39. Okamoto H, Takuwa N, Yokomizo T, Sugimoto N, Sakurada S, Shigematsu H, Takuwa Y (2000) Inhibitory regulation of Rac activation, membrane ruffling, and cell migration by the $\mathrm{G}$ protein-coupled sphingosine1-phosphate receptor EDG5 but not EDG1 or EDG3. Mol Cell Biol 20:9247-9261.

40. Sugimoto N, Takuwa N, Okamoto H, Sakurada S, Takuwa Y (2003) Inhibitory and stimulatory regulation of Rac and cell motility by the G12/13-Rho and Gi pathways integrated downstream of a single $G$ proteincoupled sphingosine-1-phosphate receptor isoform. Mol Cell Biol 23:1534-1545.

41. Ryu Y, Takuwa N, Sugimoto N, Sakurada S, Usui S, Okamoto H, Matsui O, Takuwa Y (2002) Sphingosine1-phosphate, a platelet-derived lysophospholipid mediator, negatively regulates cellular Rac activity and cell migration in vascular smooth muscle cells. Circ Res 90:325-332.

42. Tamama K, Tomura H, Sato K, Malchinkhuu E, Damirin A, Kimura T, Kuwabara A, Murakami M, Okajima F (2005) High-density lipoprotein inhibits migration of vascular smooth muscle cells through its sphingosine 1-phosphate component. Atherosclerosis 178:19-23.

43. Damirin A, Tomura H, Komachi M, Liu JP, Mogi C, Tobo M, Wang JQ, Kimura T, Kuwabara A, Yamazaki Y, Ohta H, Im DS, Sato K, Okajima F (2007) Role of lipoprotein-associated lysophospholipids in migratory activity of coronary artery smooth muscle cells. Am J Physiol Heart Circ Physiol 292:2513-2522.

44. Takashima SI, Sugimoto N, Takuwa N, Okamoto Y, Yoshioka K, Takamura M, Takata S, Kaneko S, Takuwa Y (2008) G12/13 and Gq mediate S1P2-induced inhibition of Rac and migration in vascular smooth muscle in a manner dependent on Rho but not Rho kinase. Cardiovasc Res 79:689-697.

45. Lockman K, Hinson JS, Medlin MD, Morris D, Taylor JM, Mack CP (2004) Sphingosine 1-phosphate stimulates smooth muscle cell differentiation and proliferation by activating separate serum response factor cofactors. J Biol Chem 279:42422-42430.

46. Wamhoff BR, Lynch KR, Macdonald TL, Owens GK (2008) Sphingosine-1-phosphate receptor subtypes differentially regulate smooth muscle cell phenotype. Arterioscler Thromb Vasc Biol 28:1454-1461.

47. Shimizu T, Nakazawa T, Cho A, Dastvan F, Shilling D,
Daum G, Reidy MA (2007) Sphingosine 1-phosphate receptor 2 negatively regulates neointimal formation in mouse arteries. Circ Res 101:995-1000.

48. Tosaka M, Okajima F, Hashiba Y, Saito N, Nagano T, Watanabe T, Kimura T, Sasaki T (2001) Sphingosine 1-phosphate contracts canine basilar arteries in vitro and in vivo: possible role in pathogenesis of cerebral vasospasm. Stroke 32:2913-2919.

49. Coussin F, Scott RH, Wise A, Nixon GF (2002) Comparison of sphingosine 1-phosphate-induced intracellular signaling pathways in vascular smooth muscles: differential role in vasoconstriction. Circ Res 91:151-157.

50. Salomone S, Yoshimura S, Reuter U, Foley M, Thomas SS, Moskowitz MA, Waeber C (2003) S1P3 receptors mediate the potent constriction of cerebral arteries by sphingosine-1-phosphate. Eur J Pharmacol 469:125134.

51. Salomone S, Potts EM, Tyndall S, Ip PC, Chun J, Brinkmann V, Waeber C (2008) Analysis of sphingosine 1-phosphate receptors involved in constriction of isolated cerebral arteries with receptor null mice and pharmacological tools. Br J Pharmacol 153:140-147.

52. Levkau B, Hermann S, Theilmeier G, van der Giet M, Chun J, Schober O, Schafers M (2004) High-density lipoprotein stimulates myocardial perfusion in vivo. Circulation 110:3355-3359.

53. Ohmori T, Yatomi Y, Osada M, Kazama F, Takafuta T, Ikeda H, Ozaki Y (2003) Sphingosine 1-phosphate induces contraction of coronary artery smooth muscle cells via S1P2. Cardiovasc Res 58:170-177.

54. Kwon YG, Min JK, Kim KM, Lee DJ, Billiar TR, Kim YM (2001) Sphingosine 1-phosphate protects human umbilical vein endothelial cells from serum-deprived apoptosis by nitric oxide production. $\mathrm{J}$ Biol Chem 276:10627-10633.

55. Wang F, Van Brocklyn JR, Hobson JP, Movafagh S, Zukowska-Grojec Z, Milstien S, Spiegel S (1999) Sphingosine 1-phosphate stimulates cell migration through a G(i)-coupled cell surface receptor. Potential involvement in angiogenesis. J Biol Chem 274:3534335350.

56. Liu F, Verin AD, Wang P, Day R, Wersto RP, Chrest FJ, English DK, Garcia JG (2001) Differential regulation of sphingosine-1-phosphate- and VEGF-induced endothelial cell chemotaxis. Involvement of G(ialpha2)linked Rho kinase activity. Am J Respir Cell Mol Biol 24:711-719.

57. Kimura T, Sato K, Malchinkhuu E, Tomura H, Tamama K, Kuwabara A, Murakami M, Okajima F (2003) Highdensity lipoprotein stimulates endothelial cell migration and survival through sphingosine 1-phosphate and its receptors. Arterioscler Thromb Vasc Biol 23:12831288.

58. Morales-Ruiz M, Lee MJ, Zollner S, Gratton JP, 
Scotland R, Shiojima I, Walsh K, Hla T, Sessa WC (2001) Sphingosine 1-phosphate activates Akt, nitric oxide production, and chemotaxis through a Gi protein/ phosphoinositide 3-kinase pathway in endothelial cells. J Biol Chem 276:19672-19677.

59. Rikitake Y, Hirata K, Kawashima S, Ozaki M, Takahashi T, Ogawa W, Inoue N, Yokoyama M (2002) Involvement of endothelial nitric oxide in sphingosine-1-phosphate-induced angiogenesis. Arterioscler Thromb Vasc Biol 22:108-114.

60. Arikawa K, Takuwa N, Yamaguchi H, Sugimoto N, Kitayama J, Nagawa H, Takehara K, Takuwa Y (2003) Ligand-dependent inhibition of B16 melanoma cell migration and invasion via endogenous S1P2 G proteincoupled receptor. Requirement of inhibition of cellular RAC activity. J Biol Chem 278:32841-32851.

61. Lepley D, Paik JH, Hla T, Ferrer F (2005) The G protein-coupled receptor S1P2 regulates Rho/Rho kinase pathway to inhibit tumor cell migration. Cancer Res 65:3788-3795.

62. Malchinkhuu E, Sato K, Maehama T, Mogi C, Tomura $\mathrm{H}$, Ishiuchi S, Yoshimoto Y, Kurose H, Okajima F (2008) S1P(2) receptors mediate inhibition of glioma cell migration through Rho signaling pathways independent of PTEN. Biochem Biophys Res Commun 366:963-968.

63. Inoki I, Takuwa N, Sugimoto N, Yoshioka K, Takata S, Kaneko S, Takuwa Y (2006) Negative regulation of endothelial morphogenesis and angiogenesis by S1P2 receptor. Biochem Biophys Res Commun 346:293-300.

64. Chae SS, Paik JH, Furneaux H, Hla T (2004) Requirement for sphingosine 1-phosphate receptor-1 in tumor angiogenesis demonstrated by in vivo RNA interference. J Clin Invest 114:1082-1089.

65. Visentin B, Vekich JA, Sibbald BJ, Cavalli AL, Moreno KM, Matteo RG, Garland WA, Lu Y, Yu S, Hall HS, Kundra V, Mills GB, Sabbadini RA (2006) Validation of an anti-sphingosine-1-phosphate antibody as a potential therapeutic in reducing growth, invasion, and angiogenesis in multiple tumor lineages. Cancer Cell 9:225-238.

66. Garcia JG, Liu F, Verin AD, Birukova A, Dechert MA, Gerthoffer WT, Bamberg JR, English D (2001) Sphingosine 1-phosphate promotes endothelial cell barrier integrity by Edg-dependent cytoskel et al. rearrangement. J Clin Invest 108:689-701.

67. Huang YT, Chen SU, Chou CH, Lee H (2008) Sphingosine 1-phosphate induces platelet/endothelial cell adhesion molecule-1 phosphorylation in human endothelial cells through cSrc and Fyn. Cell Signal 20:1521-1527.

68. Ilan N, Madri JA (2003) PECAM-1: old friend, new partners. Curr Opin Cell Biol 15:515-524.

69. Biswas P, Canosa S, Schoenfeld D, Schoenfeld J, Li P, Cheas LC, Zhang J, Cordova A, Sumpio B, Madri JA
(2006) PECAM-1 affects GSK-3beta-mediated betacatenin phosphorylation and degradation. Am J Pathol 169:314-324.

70. Singleton PA, Moreno-Vinasco L, Sammani S, Wanderling SL, Moss J, Garcia JG (2007) Attenuation of vascular permeability by methylnaltrexone: role of mOP-R and S1P3 transactivation. Am J Respir Cell Mol Biol 37:222-231.

71. McVerry BJ, Garcia JG (2005) In vitro and in vivo modulation of vascular barrier integrity by sphingosine 1-phosphate: mechanistic insights. Cell Signal 17: 131-139.

72. Singleton PA, Dudek SM, Ma SF, Garcia JG (2006) Transactivation of sphingosine 1-phosphate receptors is essential for vascular barrier regulation. Novel role for hyaluronan and CD44 receptor family. J Biol Chem 281:34381-34393.

73. Sanchez T, Skoura A, Wu MT, Casserly B, Harrington EO, Hla T (2007) Induction of vascular permeability by the sphingosine-1-phosphate receptor-2 (S1P2R) and its downstream effectors ROCK and PTEN. Arterioscler Thromb Vasc Biol 27:1312-1318.

74. Peng X, Hassoun PM, Sammani S, McVerry BJ, Burne MJ, Rabb H, Pearse D, Tuder RM, Garcia JG (2004) Protective effects of sphingosine 1-phosphate in murine endotoxin-induced inflammatory lung injury. Am J Respir Crit Care Med 169:1245-1251.

75. Gon Y, Wood MR, Kiosses WB, Jo E, Sanna MG, Chun J, Rosen H (2005) S1P3 receptor-induced reorganization of epithelial tight junctions compromises lung barrier integrity and is potentiated by TNF. Proc Natl Acad Sci USA 102:9270-9275.

76. Shimamura K, Takashiro Y, Akiyama N, Hirabayashi T, Murayama T (2004) Expression of adhesion molecules by sphingosine 1-phosphate and histamine in endothelial cells. Eur J Pharmacol 486:141-150.

77. Lee H, Lin CI, Liao JJ, Lee YW, Yang HY, Lee CY, Hsu HY, Wu HL (2004) Lysophospholipids increase ICAM-1 expression in HUVEC through a Gi- and NFkappaB-dependent mechanism. Am J Physiol Cell Physiol 287:1657-1666.

78. Kimura T, Tomura H, Mogi C, Kuwabara A, Ishiwara M, Shibasawa K, Sato K, Ohwada S, Im DS, Kurose H, Ishizuka T, Murakami M, Okajima F (2006) Sphingosine 1-phosphate receptors mediate stimulatory and inhibitory signalings for expression of adhesion molecules in endothelial cells. Cell Signal 18:841-850.

79. Kimura T, Tomura H, Mogi C, Kuwabara A, Damirin A, Ishizuka T, Sekiguchi A, Ishiwara M, Im DS, Sato K, Murakami M, Okajima F (2006) Role of scavenger receptor class B type I and sphingosine 1-phosphate receptors in high density lipoprotein-induced inhibition of adhesion molecule expression in endothelial cells. $J$ Biol Chem 281:37457-37467.

80. Xia P, Gamble JR, Rye KA, Wang L, Hii CS, Cockerill 
P, Khew-Goodall Y, Bert AG, Barter PJ, Vadas MA (1998) Tumor necrosis factor-alpha induces adhesion molecule expression through the sphingosine kinase pathway. Proc Natl Acad Sci USA 95:14196-14201.

81. Matsushita K, Morrell CN, Lowenstein CJ (2004) Sphingosine 1-phosphate activates Weibel-Palade body exocytosis. Proc Natl Acad Sci USA 101:11483-11487.

82. Ulbrich H, Eriksson EE, Lindbom L (2003) Leukocyte and endothelial cell adhesion molecules as targets for therapeutic interventions in inflammatory disease. Trends Pharmacol Sci 24:640-647.

83. Rao RM, Yang L, Garcia-Cardena G, Luscinskas FW (2007) Endothelial-dependent mechanisms of leukocyte recruitment to the vascular wall. Circ Res 101:234-247.

84. Takeya H, Gabazza EC, Aoki S, Ueno H, Suzuki K (2003) Synergistic effect of sphingosine 1-phosphate on thrombin-induced tissue factor expression in endothelial cells. Blood 102:1693-1700.

85. Deutschman DH, Carstens JS, Klepper RL, Smith WS, Page MT, Young TR, Gleason LA, Nakajima N, Sabbadini RA (2003) Predicting obstructive coronary artery disease with serum sphingosine-1-phosphate. Am Heart $J$ 146:62-68.

86. Igarashi J, Michel T (2001) Sphingosine 1-phosphate and isoform-specific activation of phosphoinositide 3-kinase beta. Evidence for divergence and convergence of receptor-regulated endothelial nitric-oxide synthase signaling pathways. J Biol Chem 276:3628136288.

87. Bolick DT, Srinivasan S, Kim KW, Hatley ME, Clemens JJ, Whetzel A, Ferger N, Macdonald TL, Davis MD, Tsao PS, Lynch KR, Hedrick CC (2005) Sphingosine-1-phosphate prevents tumor necrosis factor-\{alpha\}-mediated monocyte adhesion to aortic endothelium in mice. Arterioscler Thromb Vasc Biol 25:976-981.

88. Levine YC, Li GK, Michel T (2007) Agonistmodulated regulation of AMP-activated protein kinase (AMPK) in endothelial cells. Evidence for an AMPK -> Rac1 -> Akt -> endothelial nitric-oxide synthase pathway. J Biol Chem 282:20351-20364.

89. Karliner JS, Honbo N, Summers K, Gray MO, Goetzl EJ (2001) The lysophospholipids sphingosine-1-phosphate and lysophosphatidic acid enhance survival during hypoxia in neonatal rat cardiac myocytes. $J \mathrm{Mol}$ Cell Cardiol 33:1713-1717.

90. Jin ZQ, Zhou HZ, Zhu P, Honbo N, Mochly-Rosen D, Messing RO, Goetzl EJ, Karliner JS, Gray MO (2002) Cardioprotection mediated by sphingosine-1-phosphate and ganglioside GM-1 in wild-type and PKC epsilon knockout mouse hearts. Am J Physiol Heart Circ Physiol 282:H1970-1977.

91. Jin ZQ, Goetzl EJ, Karliner JS (2004) Sphingosine kinase activation mediates ischemic preconditioning in murine heart. Circulation 110:1980-1989.

92. Theilmeier G, Schmidt C, Herrmann J, Keul P, Schafers M, Herrgott I, Mersmann J, Larmann J, Hermann S, Stypmann J, Schober O, Hildebrand R, Schulz R, Heusch G, Haude M, von Wnuck Lipinski K, Herzog C, Schmitz M, Erbel R, Chun J, Levkau B (2006) High-density lipoproteins and their constituent, sphingosine-1-phosphate, directly protect the heart against ischemia/reperfusion injury in vivo via the S1P3 lysophospholipid receptor. Circulation 114:14031409.

93. Whetzel AM, Bolick DT, Srinivasan S, Macdonald TL, Morris MA, Ley K, Hedrick CC (2006) Sphingosine-1 phosphate prevents monocyte/endothelial interactions in type 1 diabetic NOD mice through activation of the S1P1 receptor. Circ Res 99:731-739.

94. Zhang B, Tomura H, Kuwabara A, Kimura T, Miura S, Noda K, Okajima F, Saku K (2005) Correlation of high density lipoprotein (HDL)-associated sphingosine 1-phosphate with serum levels of HDL-cholesterol and apolipoproteins. Atherosclerosis 178:199-205.

95. Tamama K, Okajima F (2002) Sphingosine 1-phosphate signaling in atherosclerosis and vascular biology. Curr Opin Lipidol 13:489-495.

96. Kontush A, Therond P, Zerrad A, Couturier M, NegreSalvayre A, de Souza JA, Chantepie S, Chapman MJ (2007) Preferential sphingosine-1-phosphate enrichment and sphingomyelin depletion are key features of small dense HDL3 particles: relevance to antiapoptotic and antioxidative activities. Arterioscler Thromb Vasc Biol 27:1843-1849.

97. Kobayashi N, Nishi T, Hirata T, Kihara A, Sano T, Igarashi Y, Yamaguchi A (2006) Sphingosine 1-phosphate is released from the cytosol of rat platelets in a carrier-mediated manner. J Lipid Res 47:614-621.

98. Mitra P, Oskeritzian CA, Payne SG, Beaven MA, Milstien S, Spiegel S (2006) Role of ABCC1 in export of sphingosine-1-phosphate from mast cells. Proc Natl Acad Sci USA 103:16394-16399.

99. Lee JY, Parks JS (2005) ATP-binding cassette transporter AI and its role in HDL formation. Curr Opin Lipidol 16:19-25.

100. Cavelier C, Lorenzi I, Rohrer L, von Eckardstein A (2006) Lipid efflux by the ATP-binding cassette transporters ABCA1 and ABCG1. Biochim Biophys Acta 1761:655-666.

101. Yokoyama S (2006) ABCA1 and biogenesis of HDL. $J$ Atheroscler Thromb 13:1-15.

102. Sato K, Malchinkhuu E, Horiuchi Y, Mogi C, Tomura H, Tosaka M, Yoshimoto Y, Kuwabara A, Okajima F (2007) HDL-like lipoproteins in cerebrospinal fluid affect neural cell activity through lipoprotein-associated sphingosine 1-phosphate. Biochem Biophys Res Commun 359:649-654.

103. Sato K, Malchinkhuu E, Horiuchi Y, Mogi C, Tomura 
H, Tosaka M, Yoshimoto Y, Kuwabara A, Okajima F (2007) Critical role of ABCA1 transporter in sphingosine 1-phosphate release from astrocytes. $J$ Neurochem 103: 2610-2619.

104. Walter M, Reinecke H, Nofer JR, Seedorf U, Assmann G (1995) HDL3 stimulates multiple signaling pathways in human skin fibroblasts. Arterioscler Thromb Vasc Biol 15:1975-1986.

105. Nofer JR, Walter M, Kehrel B, Wierwille S, Tepel M, Seedorf U, Assmann G (1998) HDL3-mediated inhibition of thrombin-induced platelet aggregation and fibrinogen binding occurs via decreased production of phosphoinositide-derived second messengers 1,2-diacylglycerol and inositol 1,4,5-tris-phosphate. Arterioscler Thromb Vasc Biol 18:861-869.

106. Sachinidis A, Kettenhofen R, Seewald S, GouniBerthold I, Schmitz U, Seul C, Ko Y, Vetter H (1999) Evidence that lipoproteins are carriers of bioactive factors. Arterioscler Thromb Vasc Biol 19:2412-2421.

107. Nofer JR, van der Giet M, Tolle M, Wolinska I, von Wnuck Lipinski K, Baba HA, Tietge UJ, Godecke A, Ishii I, Kleuser B, Schafers M, Fobker M, Zidek W, Assmann G, Chun J, Levkau B (2004) HDL induces NO-dependent vasorelaxation via the lysophospholipid receptor S1P3. J Clin Invest 113:569-581.

108. Grewal T, de Diego I, Kirchhoff MF, Tebar F, Heeren J, Rinninger F, Enrich C (2003) High density lipoprotein-induced signaling of the MAPK pathway involves scavenger receptor type BI-mediated activation of Ras. J Biol Chem 278:16478-16481.

109. Miura S, Fujino M, Matsuo Y, Kawamura A, Tanigawa H, Nishikawa H, Saku K (2003) High density lipoprotein-induced angiogenesis requires the activation of Ras/MAP kinase in human coronary artery endothelial cells. Arterioscler Thromb Vasc Biol 23:802-808.

110. Nofer JR, Geigenmuller S, Gopfert C, Assmann G, Buddecke E, Schmidt A (2003) High density lipoprotein-associated lysosphingolipids reduce E-selectin expression in human endothelial cells. Biochem Biophys Res Commun 310:98-103.

111. Lee MJ, Thangada S, Paik JH, Sapkota GP, Ancellin N, Chae SS, Wu M, Morales-Ruiz M, Sessa WC, Alessi DR, Hla T (2001) Akt-mediated phosphorylation of the $\mathrm{G}$ protein-coupled receptor EDG-1 is required for endothelial cell chemotaxis. Mol Cell 8:693-704.

112. Argraves KM, Gazzolo PJ, Groh EM, Wilkerson BA, Matsuura BS, Twal WO, Hammad SM, Argraves WS (2008) HDL-associated sphingosine-1-phosphate promotes endothelial barrier function. $J$ Biol Chem 283:25074-25081.

113. Norata GD, Callegari E, Marchesi M, Chiesa G, Eriksson P, Catapano AL (2005) High-density lipoproteins induce transforming growth factor-beta 2 expression in endothelial cells. Circulation 111: 2805-2811.

114. Norata GD, Marchesi P, Pirillo A, Uboldi P, Chiesa
G, Maina V, Garlanda C, Mantovani A, Catapano AL (2008) Long pentraxin 3, a key component of innate immunity, is modulated by high-density lipoproteins in endothelial cells. Arterioscler Thromb Vasc Biol 28:925-931.

115. von Otte S, Paletta JR, Becker S, Konig S, Fobker M, Greb RR, Kiesel L, Assmann G, Diedrich K, Nofer JR (2006) Follicular fluid high density lipoprotein-associated sphingosine 1-phosphate is a novel mediator of ovarian angiogenesis. J Biol Chem 281:5398-5405.

116. Tolle M, Pawlak A, Schuchardt M, Kawamura A, Tietge UJ, Lorkowski S, Keul P, Assmann G, Chun J, Levkau B, van der Giet M, Nofer JR (2008) HDLassociated lysosphingolipids inhibit NAD(P)H oxidasedependent monocyte chemoattractant protein-1 production. Arterioscler Thromb Vasc Biol 28:1542-1548.

117. Yuhanna IS, Zhu Y, Cox BE, Hahner LD, OsborneLawrence S, Lu P, Marcel YL, Anderson RG, Mendelsohn ME, Hobbs HH, Shaul PW (2001) Highdensity lipoprotein binding to scavenger receptor-BI activates endothelial nitric oxide synthase. Nat Med 7:853-857.

118. Mineo C, Shaul PW (2006) Circulating cardiovascular disease risk factors and signaling in endothelial cell caveolae. Cardiovasc Res 70:31-41.

119. Assanasen C, Mineo C, Seetharam D, Yuhanna IS, Marcel YL, Connelly MA, Williams DL, de la LleraMoya M, Shaul PW, Silver DL (2005) Cholesterol binding, efflux, and a PDZ-interacting domain of scavenger receptor-BI mediate HDL-initiated signaling. $J$ Clin Invest 115:969-977.

120. Zhu W, Saddar S, Seetharam D, Chambliss KL, Longoria C, Silver DL, Yuhanna IS, Shaul PW, Mineo C (2008) The scavenger receptor class B type I adaptor protein PDZK1 maintains endothelial monolayer integrity. Circ Res 102:480-487.

121. Gong M, Wilson M, Kelly T, Su W, Dressman J, Kincer J, Matveev SV, Guo L, Guerin T, Li XA, Zhu W, Uittenbogaard A, Smart EJ (2003) HDL-associated estradiol stimulates endothelial NO synthase and vasodilation in an SR-BI-dependent manner. $J$ Clin Invest 111:1579-1587.

122. Tso C, Martinic G, Fan WH, Rogers C, Rye KA, Barter PJ (2006) High-density lipoproteins enhance progenitor-mediated endothelium repair in mice. Arterioscler Thromb Vasc Biol 26:1144-1149.

123. Sumi M, Sata M, Miura S, Rye KA, Toya N, Kanaoka Y, Yanaga K, Ohki T, Saku K, Nagai R (2007) Reconstituted high-density lipoprotein stimulates differentiation of endothelial progenitor cells and enhances ischemia-induced angiogenesis. Arterioscler Thromb Vasc Biol 27:813-818.

124. van Oostrom O, Nieuwdorp M, Westerweel PE, Hoefer IE, Basser R, Stroes ES, Verhaar MC (2007) Reconstituted HDL increases circulating endothe- 
lial progenitor cells in patients with type 2 diabetes. Arterioscler Thromb Vasc Biol 27:1864-1865.

125. Noor R, Shuaib U, Wang CX, Todd K, Ghani U, Schwindt B, Shuaib A (2007) High-density lipoprotein cholesterol regulates endothelial progenitor cells by increasing eNOS and preventing apoptosis. Atherosclerosis 192:92-99.

126. Walter DH, Rochwalsky U, Reinhold J, Seeger F, Aicher A, Urbich C, Spyridopoulos I, Chun J, Brinkmann V, Keul P, Levkau B, Zeiher AM, Dimmeler S, Haendeler J (2007) Sphingosine-1-phosphate stimulates the functional capacity of progenitor cells by activation of the CXCR4-dependent signaling pathway via the S1P3 receptor. Arterioscler Thromb Vasc Biol 27:275-282.

127. Norata GD, Callegari E, Inoue H, Catapano AL (2004) HDL 3 induces cyclooxygenase- 2 expression and prostacyclin release in human endothelial cells via a p38 MAPK/CRE-dependent pathway: effects on COX-2/ PGI-synthase coupling. Arterioscler Thromb Vasc Biol 24:871-877.

128. Drew BG, Fidge NH, Gallon-Beaumier G, Kemp BE, Kingwell BA (2004) High-density lipoprotein and apolipoprotein AI increase endothelial NO synthase activi- ty by protein association and multisite phosphorylation. Proc Natl Acad Sci USA 101:6999-7004.

129. Viswambharan H, Ming XF, Zhu S, Hubsch A, Lerch P, Vergeres G, Rusconi S, Yang Z (2004) Reconstituted high-density lipoprotein inhibits thrombin-induced endothelial tissue factor expression through inhibition of RhoA and stimulation of phosphatidylinositol 3-kinase but not Akt/endothelial nitric oxide synthase. Circ Res 94:918-925.

130. Hyka N, Dayer JM, Modoux C, Kohno T, Edwards CK, 3rd, Roux-Lombard P, Burger D (2001) Apolipoprotein A-I inhibits the production of interleukin-1beta and tumor necrosis factor-alpha by blocking contact-mediated activation of monocytes by $\mathrm{T}$ lymphocytes. Blood 97:2381-2389.

131. Nofer JR, Feuerborn R, Levkau B, Sokoll A, Seedorf U, Assmann G (2003) Involvement of Cdc42 signaling in apoA-I-induced cholesterol efflux. J Biol Chem 278:53055-53062.

132. Haidar B, Denis M, Marcil M, Krimbou L, Genest J, Jr. (2004) Apolipoprotein A-I activates cellular cAMP signaling through the ABCA1 transporter. J Biol Chem 279:9963-9969. 